\title{
Pengaruh Bahan Ajar Muatan Lokal Mengenal Potensi Bengkulu Terhadap Hasil Belajar Siswa
}

\section{Wiwin Iswara}

Universitas Bengkulu

iswarawiwin@gmail.com

\author{
Ansyori Gunawan \\ Universitas Bengkulu \\ ansyori.pgsdunib@gmail.com
}

\section{Dalifa}

Universitas Bengkulu

dalifa.abdullah@gmail.com

\begin{abstract}
Abstrak
Penelitian ini bertujuan untuk mengetahui pengaruh bahan ajar muatan lokal mengenal potensi Bengkulu lebih dekat terhadap hasilbelajar siswa kelas IVA SD Negeri 04 Kota Bengkulu. Penelitian ini merupakan penelitian kuantitatif. Metode penelitian yang digunakan adalah PreEksperimental menggunakan One Group Pretest-Posttest Design. Populasi dalam penelitian ini adalah siswa kelas IV SD Negeri 04 Kota Bengkulu. Teknik pengambilan sampel menggunakan cluster random sampling. Sampel yang terpilih yakni IVA sebagai kelas eksperimen. Instrumen pengumpulan data yang digunakan adalah lembar tes pilihan ganda (multiple choice) yang diberikan melalui pretest dan posttest. Data hasil penelitian ini dianalisis menggunakan statistik deskriptif dan statistik inferensial yaitu uji-t. Dari hasil penelitian diketahui hasil uji-t thitungsebesar 20,79> tabel 2,064. Jadi Ha diterima dan Ho ditolak, maka dapat disimpulkan bahwa terdapat pengaruh yang signifikan penggunaan bahan ajar muatan lokal mengenal potensi Bengkulu lebih dekat terhadap hasil belajar siswa kelas IVA SD Negeri 04 Kota Bengkulu.
\end{abstract}

Kata kunci :Bahan Ajar, Muatan Lokal, Mengenal Potensi Bengkulu Lebih Dekat, Hasil Belajar

\section{Pendahuluan}

Bengkulu merupakan salah satu provinsi di Indonesia yang terdapat di pulau Sumatera. Setiap provinsi tentu memiliki potensi kekayaan alam dan budaya. Oleh sebab itu, setiap potensi kekayaan itu haruslah dijaga, dikembangkan dan dilestarikan agar tidak rusak dan hilang khususnya potensi yang dimiliki oleh provinsi Bengkulu. Hal ini mengharuskan agar setiap anggota masyarakat Bengkulu khususnya generasi penerus bangsa memiliki pengetahuan terlebih dahulu tentang daerahnya agar tumbuh kecintaan akan keadaan lingkungan dan budaya lokal di provinsi Bengkulu. Penerus bangsa yang akan dididik mulai dari usia sedini mungkin dimulai dari pendidikan paling dasar. 
Salah satu unsur seorang siswa mengenal daerah Bengkulu adalah memiliki pengetahuan tentang keadaan daerahnya. Menurut Mulyasa (2010: 273), "Keadaan daerah adalah segala sesuatu yang terdapat di daerah tertentu yang pada dasarnya berkaitan dengan lingkungan alam, lingkungan sosial dan ekonomi, serta lingkungan budaya". Oleh sebab itu, salah satu upaya untuk mengenalkan keadaan daerah khususnya provinsi Bengkulu kepada setiap siswa adalah melalui sebuah proses pembelajaran di sekolah. Proses pembelajaran yang dilakukan melalui sebuah mata pelajaran khusus yang membahas tentang keadaan lokal dapat dilaksanakan melalui mata pelajaran muatan lokal.

Melalui mata pelajaran muatan lokal, siswa diberikan pengetahuan tentang provinsi Bengkulu. Mata pelajaran muatan lokal ini memberikan pengetahuan kepada siswa tentang provinsi Bengkulu agar siswa memiliki pemahaman sehingga tidak merasa asing dengan lingkungannya dan dapat meningkatnya pengetahuan yang dimiliki siswa tentang kekayaan alam, sosial serta budaya lokal yang dimiliki oleh provinsi Bengkulu. Mata pelajaran muatan lokal ini sangatlah penting untuk diajarkan kepada siswa. Arifin (2014: 205), menyatakan bahwa, "Secara khusus, muatan lokal adalah program pendidikan dalam bentuk mata pelajaran yang isi dan media penyampaiannya dikaitkan dengan lingkungan alam, lingkungan sosial, dan lingkungan budaya serta kebutuhan daerah yang wajib dipelajari peserta didik di daerah itu."

Belajar adalah proses yang kompleks yang akan menentukan tindakan dan perilaku siswa. Siswa merupakan penentu terjadinya atau tidak terjadinya proses belajar (Dimyati, 2009: 7). Pembelajaran muatan lokal haruslah diajarkan kepada siswa sehingga siswa memiliki pengetahuan yang kompleks tentang daerahnya. Muatan lokal adalah mata pelajaran yang di dalamnya memuat karakteristik suatu daerah. Muatan lokal memberikan peranan penting bagi pendidikan anak karena muatan lokal ini memiliki tujuan agar setiap siswa dapat mengenali karakteristik yang dimiliki daerahnya.

Melalui mata pelajaran muatan lokal, siswa diharapkan dapat mengetahui letak geografis provinsi Bengkulu, batas-batas wilayah Bengkulu, bagaimana pembagian wilayah di provinsi Bengkulu dan mengenal bagaimana kondisi alam dan kondisi sosial ekonomi dan kondisi budaya di provinsi Bengkulu. Oleh sebab itu, diperlukan sebuah bahan ajar untuk mendukung proses pembelajaran yang baik. Upaya yang dilakukan guru agar siswa dapat dengan mudah mengenali provinsi Bengkulu adalah dengan menggunakan bahan ajar yang menarik.

Menurut Belawati (2006: 1.3), bahan ajar itu bersifat unik dan spesifik serta sistematika cara penyampaiannya disesuaikan dengan karakteristik mata pelajaran dan karakteristik siswa yang menggunakannya. Oleh sebab itu, bahan ajar yang diberikan kepada siswa harus bisa menarik minat siswa untuk membacanya. Hal ini akan memicu tumbuhnya semangat siswa dalam belajar sehingga pengetahuan siswa tentang provinsi Bengkulu akan luas.

Bahan ajar yang digunakan dalam penelitian ini yaitu bahan ajar muatan lokal yang berisi materi tentang mengenal potensi Bengkulu yang terdiri dari potensi alam, potensi sosial ekonomi dan potensi budaya yang ada di provinsi Bengkulu. Bahan ajar muatan lokal mengenal potensi Bengkulu lebih dekat dalam penelitian ini merupakan bahan ajar yang disusun berdasarkan kisi-kisi dari tim penelitian payung yang dilakukan oleh Dosen Universitas Bengkulu Program Studi Pendidikan Guru Sekolah Dasar. Melalui bahan ajar ini, diharapkan akan memberikan pengetahuan kepada siswa sekolah dasar sehingga dapat meningkatkan hasil belajar siswa.

Berdasarkan hasil penelitian Widiyanto (2015: 5) yang berjudul "Pengembangan Bahan Ajar Berbasis Fenomena Alam untuk Meningkatkan Pemahaman Konsep dan Keterampilan Generik Siswa", didapatkan hasil penelitian yang menunjukkan 
bahwa validitas pengembanga bahan ajar mendapat skor 3,26 terdapat pada interval 3,25 $\leq \mathrm{Va}<4,00$ dalam kriteria sangat valid dibuktikan dengan rata-rata penilaian validator tingkat validitas silabus sebesar 3,19 (valid), RPP sebesar 2,97 (valid), dan alat evaluasi sebesar 3,48 (sangat valid). Hasil belajar pemahaman konsep setelah pembelajaran mengalami peningkatan yang signifikan dibuktikan dengan hasil uji paired sample t-test dengan t-hitung $=4,2976>$ ttabel $=2,131$ yang berarti melebihi $\mathrm{KKM}=65$, serta mencapai ketuntasan belajar klasikal dibuktikan dengan hasil Zhitung $=1,218>$ Ztabel $=0,882$ atau $75 \%$. Hasil uji t untuk data hasil belajar dari kelas eksperimen dan kelas kontrol diperoleh nilai t-hitung $=0,7421>\mathrm{t}$ tabel $=0,032$ rata-rata hasil belajar pada kelas eksperiman lebih tinggi dari kelas kontrol. Kepraktisan bahan ajar yang dikembangkan memberikan $100 \%$ respon positif. Dari hasil penelitian dapat disimpulkan bahwa bahan ajar berbasis fenomena alam layak digunakan dalam pembelajaran dan dapat meningkatkan hasil belajar siswa.

Provinsi Bengkulu adalah provinsi yang kaya. Kekayaan alam berupa wilayah daratan dan wilayah perairan yang harus dijaga. Oleh sebab itu, kekayaan dan kebudayaan yang dimiliki oleh provinsi Bengkulu harus dijaga dan dilestarikan, khususnya oleh generasi penerus bangsa. Kebudayaan berupa tari-tarian dan pakaian adat harus dikembangkan sesuai dengan perkembangan zaman, namun harus tetap mempertahankan ciri khas kebudayaan tersebut agar tidak hilang sehingga sangat penting bagi seorang siswa untuk mengenali potensi yang dimiliki oleh provinsi Bengkulu. Apabila siswa tidak memiliki pengetahuan tentang Bengkulu maka identitas masyarakat Bengkulu akan terancam hilang. Oleh sebab itu, anak-anak bangsa harus kita bekali dengan pengetahuan berbasis muatan lokal untuk menumbuhkan pengetahuan pada diri anak tentang daerahnya.

\section{Metode}

Jenis penelitian yang digunakan dalam penelitian ini adalah penelitian kuantitatif dan menggunakan metode pra-eksperimen (Pre-Eksperimental) yang merupakan penelitian sistematis untuk menguji hipotesis hubungan sebab-akibat.

Desain yang digunakan dalam penelitian ini adalah desain Satu Kelompok PretesPostes (One Group Pretest-Posttest). Dalam desain ini, sebelum perlakuan diberikan terlebih dahulu sampel diberi pretest dan di akhir pembelajaran sampel diberi posttest. Pada awal kegiatan pembelajaran, siswa akan diberikan tes (pretest) untuk mengetahui kemampuan awal siswa terhadap pengenalan tentang Bengkulu sebelum diberikan treatment. Kemudian siswa diberikan treatment berupa pembelajaran dengan menggunakan bahan ajar muatan lokal mengenal potensi Bengkulu lebih dekat. Setelah diberikan treatment, di akhir pembelajaran siswa diberikan tes (posttest) untuk mengetahui kemampuan akhir siswa terhadap pengenalan tentang Bengkulu, maka besar pengaruh bahan ajar muatan lokal mengenal potensi Bengkulu lebih dekat terhadap hasil belajar siswa adalah $\left(\mathrm{O}_{2}-\mathrm{O}_{1}\right)$.

\section{Partisipan}

Populasi merupakan kelompok yang menarik peneliti, kelompok tersebut oleh peneliti dijadikan sebagai objek untuk menggeneralisasikan hasil penelitian (Fraenkel dan Wallen dalam Winarni, 2011: 94). Populasi adalah keseluruhan objek penelitian. Populasi dalam penelitian ini adalah seluruh siswa kelas IV SD N 04 Kota Bengkulu tahun ajaran 2016/2017 yang berjumlah 55 orang yang terdiri dari dua kelas yaitu kelas IVA yang berjumlah 25 orang siswa dan kelas IVB yang berjumlah 30 orang siswa.

Sampel adalah bagian dari populasi. Sampel dapat didefinisikan sebagai sembarang himpunan yang merupakan bagian dari suatu populasi (Winarni, 2011: 96). Teknik pengambilan sampel dalam penelitian ini adalah cluster random sampling. Siswa 
kelas IV di SDN 04 Kota Bengkulu yang terdiri dari kelas IVA dan IVB diundi, sehingga diperoleh hasil kelas IVA menjadi kelas eksperimen. Jadi sampel dalam penelitian ini adalah siswa kelas IVA SD N 04 Kota Bengkulu. Jumlah sampel yang ada dalam penelitian ini yaitu berjumlah 25 orang siswa.

\section{Instrumen}

Instrumen penelitian sering dikenal dengan alat ukur. Menurut Sugiyono (2013:102)instrumen penelitian merupakan suatualat yang digunakan mengukur fenomena alam maupun sosial yang diamati karena pada prinsipnya meneliti adalah melakukan pengukuran, maka dalam melakukan penelitian harus ada alat ukur yang baik. Dari pernyataan tersebut dapat disimpulkan bahwa instrumen penelitian merupakan suatu alat bantu yang digunakan oleh peneliti dalam mengumpulkan data, sehingga dapat diperoleh kemudahan dalam mengumpulkan data sesuai dengan harapan.

Ada beberapa alat yang digunakan untuk mengumpulkan data dalam penelitian yaitu wawancara, angket, observasi, evaluasi dan tes. Dalam penelitian ini, alat yang digunakan untuk mengumpulkan data yaitu berupa tes. Menurut Winarni (2011:155) beberapa macam tes yang digunakan dalam penilaian pendidikan yaitu tes kepribadian, tes bakat, tes intelegensi, tes minat, tes prestasi, dan tes sikap. Jenis tes yang digunakan dalam penelitian ini adalah tes intelegensi tentang pengetahuan (kognitif) karena digunakan untuk mengukur hasil belajar siswa. Tes pengetahuan (kognitif) yang digunakan dalam penelitian ini berbentuk pilihan ganda (multiple choices) dengan alternatif 4 jawaban ( $a, b, c$ dan d).

\section{Teknik Pengumpulan Data}

Teknik pengumpulan data dalam penelitian ini adalah pemberian tes dalam bentuk pretest dan posttest.Pretest dan postest yang diberikan dalam pengumpulan data pada penelitian ini adalah berupa tes tertulis dalam bentuk soal objektif dengan soal yang sama.

\section{Teknik Analisis Data}

Teknik analisis data yang digunakan dalam penelitian ini adalah analisa kuantitatif yang terdiri dari analisis statistik deskriptif,analisis inferensial.

\section{Hasil}

Hasil belajar siswa aspek kognitif terlihat dari nilai pretest dan posttest yang menunjukkan hasil belajar posttest lebih baik dibandingkan dengan pretest. Pretest dilakukan sebelum memberi perlakuan pada kelas eksperimen yang mengikuti pembelajaran Muatan Lokal dengan menggunakan bahan ajar mengenal potensi Bengkulu lebh dekat. Posttest dilakukan setelah memberi perlakuan kepada siswa kelas eksperimen yang mengikuti pembelajaran Muatan Lokal dengan menggunakan bahan ajar mengenal potensi Bengkulu lebh dekat.

Berdasarkan hasil analisis hasil belajar siswa sebelum mengikuti pembelajaran menggunakan bahan ajar mengenal Bengkulu lebih dekat (pretest) dan hasil belajar siswa setelah mengikuti pembelajaran menggunakan bahan ajar mengenal Bengkulu lebih dekat (posttest) didapat hasil bahwa rata-rata nilai posttest sebesar 80,78 lebih baik dari rata-rata nilai pretest sebesar 34,06.

\section{Pembahasan}

Penelitian berjudul pengaruh bahan ajar muatan lokal mengenal potensi Bengkulu lebih dekat terhadap hasil belajar siswa kelas IVA SD Negeri 04 Kota Bengkulu ini 
bertujuan untuk mengetahui penggunaan bahan ajar muatan lokal mengenal potensi Bengkulu lebih dekat terhadap hasil belajar siswa kelas IVA SD Negeri 04 Kota Bengkulu.

Berdasarkan hasil penelitian dan uji hipotesis yang telah dilakukan menunjukkan bahwa pembelajaran dengan menggunakan bahan ajar muatan lokal mengenal potensi Bengkulu lebih dekat memberikan pengaruh terhadap hasil belajar aspek kognitif pada pembelajaran Muatan Lokal siswa kelas IVA di SD Negeri 04 Kota Bengkulu. Hal ini terlihat dari hasil belajar aspek kognitif pretest dan posttest yang menunjukkan hasil belajar posttest lebih baik dibandingkan dengan hasil belajar pretest.

Bahan ajar muatan lokal mengenal potensi Bengkulu lebih dekat dalam penelitian ini merupakan bahan ajar yang disusun berdasarkan kisi-kisi dari tim penelitian payung yang dilakukan oleh Dosen PGSD FKIP UNIB tahun 2016. Bahan ajar dalam penelitian ini yakni bahan ajar muatan lokal kelas IV bab 1 tentang mengenal potensi Bengkulu lebih dekat. Bahan ajar muatan lokal bab 1 mengenal potensi Bengkulu lebih dekat ini berisi materi tentang letak geografis provinsi Bengkulu, pembagian wilayah di provinsi Bengkulu, potensi alam, potensi sosial ekonomi dan potensi budaya yang ada di provinsi Bengkulu.

Bahan ajar ini memiliki keunggulan yakni materi yang disajikan dibuat semenarik mungkin sehingga siswa tertarik untuk membacanya. Selain itu, bahan ajar ini dilengkapi dengan gambar beserta keterangannya agar siswa dapat memahami materi didalamnya, sehingga memudahkan siswa dalam belajar. Hal ini sesuai dengan pendapat Abidin (2012: 33) yang mengungkapkan bahwa bahan ajar merupakan materi pembelajaran yang terdiri dari seperangkat fakta, konsep, prinsip dan prosedur dan generalisasi yang dirancang secara khusus untuk memudahkan pembelajaran.

Pembelajaran muatan lokal tentang mengenal potensi Bengkulu lebih dekat ini belum pernah dipelajari oleh siswa kelas IVA SDN 04 Kota Bengkulu khususnya pada mata pelajaran muatan lokal, sehingga pada saat pelaksanaan pretest, siswa belum memiliki pengetahuan yang luas tentang potensi Bengkulu khususnya tentang letak geografis propinsi Bengkulu, pembagian wilayah di propinsi Bengkulu, kondisi alam, ekonomi, sosial dan budaya di provinsi Bengkulu. Hal ini terlihat dari rata-rata hasil belajar pretest siswa sebesar 34,06 yang menunjukkan bahwa pengetahuan awal siswa masih sangat rendah. Namun, pada proses pelaksanaan pembelajaran menggunakan bahan ajar muatan lokal mengenal potensi Bengkulu lebih dekat ini, rasa ingin tahu siswa sangat tinggi. Hal ini disebabkan karena siswa belum memiliki pengetahuan yang luas tentang potensi Bengkulu sehingga merangsang rasa ingin tahu siswa ketika mempelajari muatan lokal menggunakan bahan ajar mengenal potensi Bengkulu lebih dekat sehingga ketika pelaksanaan posttest, hasil belajar siswa menjadi lebih baik. Hal ini terlihat dari rata-rata hasil belajar posstest siswa sebesar 80,78 yang menunjukkan bahwa terjadinya kenaikan hasil belajar siswa yang cukup baik.

Pada saat pelaksanaan pembelajaran muatan lokal di kelas eksperimen, guru membagikan bahan ajar muatan lokal mengenal potensi Bengkulu lebih dekat kepada setiap siswa sehingga motivasi belajar siswa sangat tinggi. Selain itu, guru memberikan kesempatan siswa untuk membaca bahan ajar terlebih daluhu sebelum pembelajaran. Oleh sebab itu, bahan ajar ini sudah disusun secara sistematis, materi yang disajikan disertai gambar-gambar dan warna yang menarik yaitu misalnya pada materi kenampakan alam terdapat gambar pemukiman atau rumah-rumah masyarakat, bukit kaba, pegunungan, teluk dan tanjung serta perairan yeng berupa danau, laut dan pantai, bendungan. Kenampakan sosial budaya berupa gambargambar pakaian adat, tarian-tarian tradisional di provinsi Bengkulu sehingga siswa dapat tertarik untuk membacanya dan aktif dalam proses pembelajaran. Belawati 
(2006: 1.7) yang menyatakan bahwa bahan ajar yang disajikan secara menarik dalam pembelajaran dapat memberikan ketertarikan siswa untuk membaca dan memahami isi bacaan. Bahan ajar dapat membantu proses pembelajaran sehingga penggunaan bahan ajar dapat memberikan pembelajaran yang bermakna dan hasil belajar siswa lebih baik.

Berdasarkan hasil belajar siswa berupa pretest dan posttest yang telah dianalisis menggunakan statistik deskriptif dan statistik inferensial. Statistik deskriptif yakni terlihat pada rata-rata posttest $(80,78)$ lebih besar dari rata-rata pretest $(34,06)$, nilai rata-rata posttest lebih besar dari nilai rata-rata pretest. Hal ini menunjukkan hasil belajar posttest siswa lebih baik dari hasil belajar pretest.

Statistik inferensial yakni terlihat bahwa thitung $(20,79)$ lebih besar dari tabel $(2,064)$ sehingga terdapat pengaruh yang signifikan penggunaan bahan ajar muatan lokal mengenal potensi Bengkulu lebih dekat terhadap hasil belajar siswa kelas IVA SD Negeri 04 Kota Bengkulu.

\section{Kesimpulan}

Berdasarkan hasil analisis data, terdapat pengaruh yang signifikan penggunaan bahan ajar muatan lokal mengenal potensi Bengkulu terhadap hasil belajar siswa. Hal ini terlihat dari thitung $(20,79)>$ tabel $(2,064)$, maka Ha diterima dan Ho ditolak.

\section{Saran}

Berdasarkan kesimpulan di atas, maka peneliti mengemukakan beberapa saran sebagai berikut:

1. Sebagai masukan bagi kepala sekolah untuk mengembangkan kurikulum muatan lokal sekolah untuk menambah pemahaman sisswa tentang potensi daerah khususnya tentang mengenal potensi Bengkulu lebih dekat.

2. Bagi guru agar dapat menggunakan bahan ajaryang sistematis dan menarik dalam proses pembelajaran muatan lokal untukmemberikan pengetahuan kepada siswa dan dapat meningkatkan keaktifan siswa.

3. Bagi peneliti lain (yang ingin menindaklanjuti penelitian ini) disarankan dapat melakukan penelitian untuk melihat pengaruh bahan ajar muatan lokal mengenal potensi Bengkulu lebih dekat terhadap hasil belajar siswa pada aspek afektif.

\section{Referensi}

Abidin, Yunus. 2012. Pembelajaran Bahasa Berbasis Pendidikan Karakter. Bandung: PT Refika Aditama.

Anderson, Lorin W.\&Krathwohl. 2010. Kerangka Landasan untuk Pembelajaran, Pengajaran, dan Asesmen. Yogyakarta: Pustaka Pelajar.

Arikunto, Suharsimi. 2010. Prosedur Penelitian Suatu Pendekatan Praktik Edisi (Revisi VII). Jakarta: Rineka Cipta.

2006. Pengembangan Program Muatan Lokal (PPML). Jakarta: Universitas Terbuka.

Arifin, Zainial. 2014. Konsep dan Model Pengembangan Kurikulum. Bandung: PT Remaja Rosdakarya.

Belawati, dkk. 2006. Pengembangan Bahan Ajar. Jakarta: Universitas Terbuka. 
Daryanto. 2014. Pengembangan Perangkat Pembelajaran. Yogyakarta: Gaya Media.

Dimyati \& Mudjiono. 2009. Belajar dan Pembelajaran. Jakarta: Rineka Cipta.

Giyarto. 2007. Selayang Pandang Bengkulu. Klaten: PT Intan Pariwara

Hernawan, Asep Herry, dkk. 2007. Pengembangan Kurikulum dan Pembelajaran. Jakarta: Universitas Terbuka.

Majid, Abdul. 2007. Perencanaan Pembeajaran Mengembangkan Standar Kompetensi Guru. Bandung: PT Remaja Rosdakarya.

Mulyasa, Enco. 2010. Kurikulum Tingkat Satuan Pendidikan. Bandung: PT Remaja Rosdakarya.

Munadi, Yudhi, 2013. Media Pembelajaran (Sebuah Pendekatan Baru). Jakarta Selatan: GP Press Group.

Pemerintah Provinsi Bengkulu. 2015. Informasi Laporan Penyelenggaraan Pemerintah Daerah Provinsi Bengkulu Tahun 2014. Bengkulu: Kantor Statistik Provinsi Bengkulu.

Rusman, 2013. Belajar dan Pembelajaran Berbasis Komputer (Mengembangkan Profesionalisme Guru Abad 21). Bandung: Alfabeta.

Sudjana, Nana. 2009. Penilaian Hasil Proses Belajar Mengajar. Bandung: PT Remaja Rosdakarya.

Sugiyono, 2016. Metode Penelitian Kuantitatif, Kualitatif dan R\&D. Bandung: Alfabeta.

Bandung: Alfabeta.

Susanto, Ahmad. 2013. Teori Belajar dan Pembelajaran di Sekolah Dasar. Jakarta: Kencana.

Widiyanto, dkk. 2015. "Pengembangan Bahan Ajar Berbasis Fenomena Alam untuk Meningkatkan Pemahaman Konsep dan Keterampilan Generik Siswa”. Jurnal Pendidikan Sekolah Dasar, 4, I, hlm. 5.

Winarni,EndangWidi. 2012. Inovasi dalam Pembelajaran IPA. Bengkulu: FKIP Universitas Bengkulu.

Bengkulu.

Yaumi, Muhammad,2013. Prinsip-prinsip Desain Pembelajaran. Jakarta: Kencana. 